\title{
Diagnostic utility of semen analysis in infertile couples: a prospective study
}

\author{
Roopali Jandial, Mehnaz Choudhary*, Kuldeep Singh
}

Department of Pathology, Government Medical College, Jammu, J\&K, India

Received: 11 June 2019

Accepted: 09 July 2019

\section{*Correspondence:}

Dr. Mehnaz Choudhary,

E-mail: mehnazchoudhary@gmail.com

Copyright: (C) the author(s), publisher and licensee Medip Academy. This is an open-access article distributed under the terms of the Creative Commons Attribution Non-Commercial License, which permits unrestricted non-commercial use, distribution, and reproduction in any medium, provided the original work is properly cited.

\begin{abstract}
Background: Infertility is defined as a failure to conceive after at least 12 months of unprotected intercourse. It is broadly established that $40 \%$ cases of infertility has male factor. Semen analyses is an imperative diagnostic tool in the valuation of the male partners of infertile couples.

Methods: We carried out a prospective study wherein semen analyses of the male partners of infertile couples presented to Department of Pathology, Government Medical College and Associate Hospital, Jammu was done. A total of 300 cases were studied and comparison of each abnormality and combined defects were subjected to incidence distribution.

Results: We analysed 300 samples in this study. Mean age of the men was 32.5 years. Duration of infertility in (200; $66.6 \%$ ) was seen in men married for less than 5 years, $(84 ; 28 \%)$ between $5-10$ years of married life and there were $(16 ; 5.3 \%)$ with more than 10 years of infertility period after marriage. Addiction to alcohol made the majority in our study $(187 ; 62.3 \%)$, followed by tobacco chewing and addiction to both tobacco chewing and alcohol consumption $(89 ; 29.6 \%)$ and $(24 ; 8 \%)$, respectively, men were amongst those with abnormal seminograms.

Conclusions: Male infertility is an alarming global health issue. Males contribute towards infertility in couples significantly and further study and assessment is required to accurately predict the importance of this.
\end{abstract}

Keywords: Infertility, Motility, Morphology, Semen, Sperm count

\section{INTRODUCTION}

Infertility is a condition with social, economical, psychological and medical impact resulting in stress, particularly in a social framework like ours, which has a strong accent on child-bearing. ${ }^{1}$ Infertility is defined as a failure to conceive after at least 12 months of unprotected intercourse. $^{2}$

Leeuwenhoek in 1677, examined his own ejaculate, under the microscope which revealed presence of living human sperm cells in a drop of semen for the first time. It is broadly established that $40 \%$ cases of infertility has male factor and female factor contributes to another $40 \%$ of the cases. Only in $20 \%$ cases, there is combined male and female factor. In India, the prevalence of primary infertility is estimated to be $10-20 \% .^{3} \mathrm{~A}$ semen analysis is an imperative diagnostic tool in the valuation of the male partners of infertile couples. Detailed and careful evaluation of the ejaculate parameters may suggest the likely causes of infertility and their identification could help to institute appropriate treatment, if accessible. ${ }^{3} \mathrm{We}$ conducted this study to find out contribution of the seminal patterns towards overall infertility due to male factors in our setting. And assess the different seminal patterns in male infertility. 


\section{METHODS}

We carried out a prospective study wherein semen analyses of the male partners of infertile couples presented to Department of Pathology, Government Medical College and Associate Hospital, Jammu was done. A total of 300 consecutive cases were taken for the study excluding patients with previous history of disease such as varicocele, cryptorchidism, epididymitis, mumps, azoospermia or surgery associated with reproductive function like vasectomy and vasectomy reversal. Detailed history was taken which included their job profile, alcohol consumption, smoking habits and medical and family history. Semen collection was done in sterile plastic containers by masturbation after 3 days of abstinence. Samples were delivered within one hour of collection and analysed by manual method. Physical and microscopic examination for volume, viscosity, sperm concentration, motility and morphology, according to WHO guidelines on semen analysis was done. A comparison of each abnormality and combined defects were subjected to incidence distribution.

\section{Statistical analysis}

For data analysis, we used Statistical Package for the Social Sciences (SPSS) version 10. Age and morphological patterns were expressed as frequency and percentage.

\section{RESULTS}

We analysed 300 samples in this prospective study. Mean age of the men in this study was 32.5 years Figure 1 .

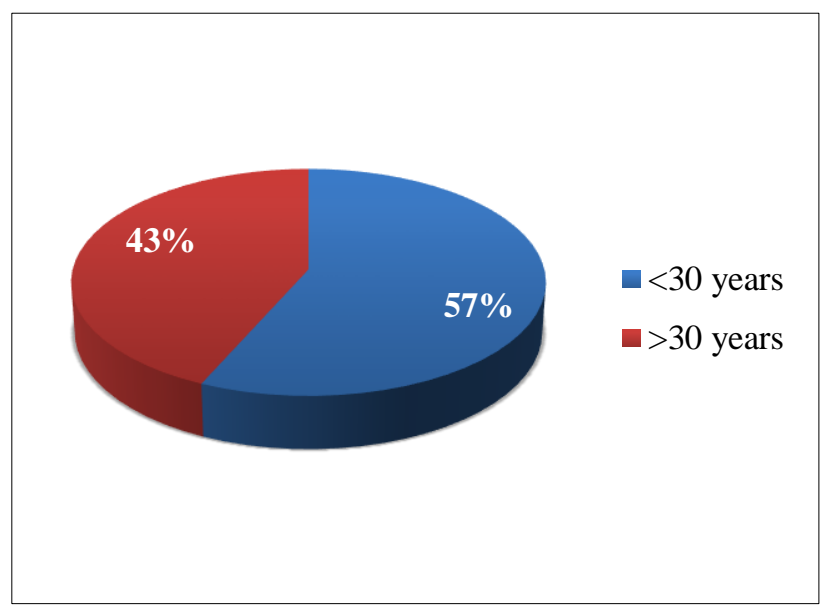

Figure 1: Number of cases according to age.

Duration of infertility in $(200 ; 66.6 \%)$ was seen in men married for less than 5 years, $(84 ; 28 \%)$ between $5-10$ years of married life and there were $(16 ; 5.3 \%)$ with more than 10 years of infertility period after marriage. Seminogram is tabulated in Table 1.

Table 1: Detailed seminogram of all patients.

\begin{tabular}{|llll|}
\hline Parameters & & No. of cases & $\%$ \\
\hline \multirow{3}{*}{ Volume (in ml) } & $<2$ & 90 & 30 \\
\cline { 2 - 4 } & $2-4$ & 190 & 63.3 \\
\cline { 2 - 4 } Sperm count (million/ml) & $4-6$ & 20 & 6.6 \\
& $<20$ & 180 & 60 \\
\hline \multirow{3}{*}{ Proportion of motility (per hpf) } & $20-40$ & 105 & 35 \\
\cline { 2 - 4 } & $>60$ & 15 & 5 \\
\hline \multirow{2}{*}{ Morphology } & $<25$ & 198 & 66 \\
\hline \multirow{2}{*}{ Pus cells } & $25-50$ & 78 & 26 \\
\cline { 2 - 4 } & $50-75$ & 19 & 6.3 \\
\cline { 2 - 4 } & $75-100$ & 5 & 1.6 \\
\hline
\end{tabular}

Addiction to alcohol made the majority in our study (187; $62.3 \%$ ), followed by tobacco chewing and addiction to both tobacco chewing and alcohol consumption (89; $29.6 \%)$ and $(24 ; 8 \%)$, respectively, men were amongst those with abnormal seminograms Figure 2.
There are very few studies in rural areas as far as male infertility is concerned. Sperm count, motility and morphological abnormality are the parameters discussed in reference to different factors in this study. Majority had abnormality in sperm motility Table 2 . 
Table 2: Depicting semen abnormality in different factors studied.

\begin{tabular}{|llllll|}
\hline \multirow{2}{*}{ Agactors } & & Abnormal sperm count & Abnormal motility & Abnormal morphology & Total \\
\hline \multirow{2}{*}{$\begin{array}{l}\text { Period of } \\
\text { infertility }\end{array}$} & $<30$ years & 50 & 100 & 20 & 170 \\
\cline { 2 - 7 } & $>30$ years & 26 & 94 & 10 & 130 \\
\hline \multirow{3}{*}{ Addiction } & 5-10 years & 10 & 92 & 58 & 200 \\
\cline { 2 - 6 } & $>10$ years & 9 & 5 & 2 & 84 \\
\cline { 2 - 6 } & Alcohol & 120 & 37 & 30 & 16 \\
\cline { 2 - 6 } & Tobacco & 59 & 14 & 14 & 89 \\
\hline
\end{tabular}

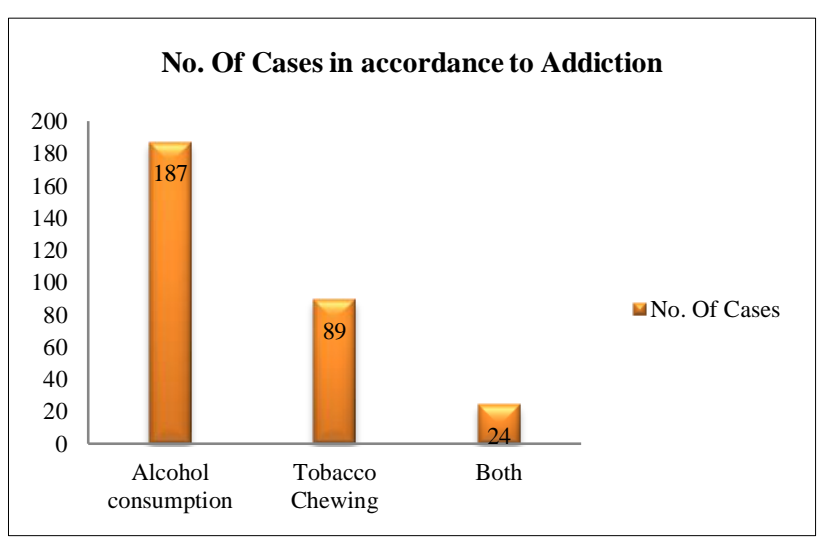

Figure 2: Number of cases in accordance to addiction.

\section{DISCUSSION}

The present study was conducted on 300 abnormal semen samples to discover the abnormalities in the samples for detection of the infertility in males. A very few studies has been conducted as far as male infertility is concerned. Semen analysis plays a vital role in the diagnosis of infertility, as it is a cost effective diagnostic tool in the valuation of the male partners of infertile couples.

The parameter considered in this study includes semen count, motility and morphology. Majority showed abnormality in sperm motility.

Mean age of the men in this study was 32.5 years. A prominent number i.e. $66.6 \%$ had duration of infertility below 5 years, $28 \%$ between 5-10 years and there were only $5.3 \%$ with more than 10 years of infertility; paralleled to studies by Jajoo et al, and Jain A et al who found $62 \%$ and $66 \%$ had duration of infertility below 5 years, respectively. ${ }^{1,3}$

In the present study as far as semen volume is concerned, $30 \%$ males had $<2 \mathrm{ml}, 63.3 \%$ had $2-4 \mathrm{ml}$ and $20 \%$ had $4-$ $6 \mathrm{ml}$. Studies conducted in Bangalore by Joshi et al showed $6 \%$ cases had semen volume of less than $2 \mathrm{ml}$, rural central Indian study by Jajoo et al and western Indian study by Jain A et al revealed that $22 \%$ and $28 \%$ of cases had semen volume of less than $2 \mathrm{ml}$, respectively. ${ }^{1,3,4}$ An international study by Onyeka CA et al stated $33.8 \%$ males had semen volume less than normal in Nigeria. ${ }^{5}$

In our study sperm count of $60 \%$ men was less than 20 million/ml which was comparable to study done by Jain A et al but disagreement was noted with Jajoo et al which revealed $25 \%$ men with less than 20 million/ml sperm count. ${ }^{1,3}$

In comparison of sperm concentration and motility; motility has a strong correlation to percentage of pregnancy and conception rate. In our study, 92\% samples showed less than $50 \%$ motile sperms/hpf which was comparable to study done by Jain A et al in western India. $^{1}$

A high number of cases showed abnormal forms in our study comprising of $68.3 \%$ which was in agreement to studies done by Jain A et al, and Jajoo et al, in western India and rural central India, respectively. ${ }^{1,3}$

In present study, $36.6 \%$ men had presence of pus cells in semen samples, which was in contrast to study conducted in West Bengal by Bhaduri (Bhattacharyya) $\mathrm{N}$ et al. ${ }^{6}$

In our study, $62.3 \%$ men had semen abnormality were addicted to alcohol, followed by $29.6 \%$ men with addiction to tobacco chewing and only $8 \%$ men were addicted to both tobacco and alcohol. Our study was in agreement with study done by Samal et al, having maximum cases with alcohol addiction but in contrast to study by Jajoo et al, which revealed majority with tobacco addiction. ${ }^{3,7}$ Chronic alcohol intake may result in male infertility by decreasing sperm volume, count, motility and also affecting the morphology..${ }^{8-10}$

Social factors like smoking, environmental conditions, and genetics are also questioned to contribute to the variation in different studies. ${ }^{11}$

Male infertility is an alarming global health issue that has not been researched or studied to truly understand its magnitude and prevalence. ${ }^{12}$ Males contribute towards infertility in couples significantly and further study and 
assessment is required to accurately predict the importance of this. And the extent to which males contribute to infertility is yet to be studied and requires more elaborate research.

\section{CONCLUSION}

Unlike female infertility, male infertility is under reported in developing countries like ours, so it's difficult to investigate exact cause and number. But in future, we can expect to conduct more research studies and contribute to find out the general causes of male infertility and can work in that direction to reduce such factors which can affect the fertility of males. There is still a great scope for further research into underlying etiology and treatment of male infertility.

\section{ACKNOWLEDGMENTS}

Authors would like to Department of Gynecology, for sending the samples, and technical staff for their cooperation.

\section{Funding: No funding sources}

Conflict of interest: None declared

Ethical approval: Not required

\section{REFERENCES}

1. Jain A, Ambrish PI, Hoogar MB, Dhar R, Wani A, Agrwal S. Role of semen analysis in the diagnosis of infertility at a tertiary care centre in Western India: a prospective study. Int $\mathbf{J}$ Reprod Contracept Obstet Gynecol. 2016;5:2389-91.

2. Rowe PJ, Comhaire FH, Hargreave TB, Mahmoud AM. WHO Manual for the Standardized Investigation, Diagnosis and Management of the Infertile Male. $1^{\text {st }}$ ed. New York: Cambridge University Press; 2000:91.

3. Jajoo S, Kalyani KR. Prevalence of abnormal semen analysis in patients of infertility at a rural setup in
Central India. Int J Reprod Contracept Obstet Gynecol. 2013;2:161-4.

4. Joshi P, Gopal N, Bhat V. Study of semen analysis patterns in infertile males. Int $\mathrm{J}$ Pharm Bio Sci. 2011;1(1):44-9.

5. Onyeka CA, Ashiru OA, Duru FI, Olorunfemi OJ, Fabunmi OO, Oluwatuyi TS. Semen analysis of 263 sample men from infertility clinic in western Nigeria. West Afr J Assist Reprod. 2012;2(1):1-16.

6. Bhaduri (Bhattacharyya) N, Sarkar AP, Dewasi N, Ghosh TK. Abnormalities in semen analysis among male partners of infertile couples: a study in a tertiary care level hospital of West Bengal, IndiaInt $\mathbf{J}$ Reprod Contracept Obstet Gynecol. 2015;4(1):100-2.

7. Samal S, Dhadwe K, Gupta U, Gupta NK. Epidemiological study of male infertility, Indian Medical Gazette. 2012:174-80.

8. Muthusami KR, Chinnaswamy P. Effect of chronic alcoholism on male fertility hormones and semen quality. Fertil Steril. 2005;84:919-24.

9. Goverde HJ, Dekker HS, Janssen HJ. Semen quality and frequency of smoking and alcohol consumptionan explorative study. Int J Fertil Menopausal Stud. 1995;40:135-8.

10. Carlsen E, Giwercman A, Keiding N, Skakkebaek NE. Evidence for decreasing quality of semen during past 50 years. BMJ. 1992;305:609-13.

11. Kidd SA, Eskenazi B, Wyrobek AJ. Effects of male age on semen quality and fertility: a review of the literature. Fertil Steril. 2001;75(2):237-48.

12. Kumar N, Singh AK. Trends of male factor infertility, an important cause of infertility: A review of literature. J Hum Reprod Sci. 2015;8:191-6.

Cite this article as: Jandial R, Choudhary M, Singh $\mathrm{K}$. Diagnostic utility of semen analysis in infertile couples: a prospective study. Int J Reprod Contracept Obstet Gynecol 2019;8:3618-21. 